\title{
SLIKA ITALIJE U PUTOPISU: \\ GETE, BAJRON, STENDAL I CRNJANSKI
}

Ključne reči putopisno, slika, (inter)tekstualnost, Italija, posredovanost

Apstrakt: Birajući, u XVIII i XIX veku, svakako, a donekle i u XX, dominantni putopisni narativ autor je želeo da pokaže kako se on konstruiše, i koliko je važan ne samo za žanr nego za književnost i kulturu uopšte. Tačnije, kako je putopis uticao i na druge žanrove, pa i neknjiževne. Zatim se bavio odnosom različitih putopisa, tj. njihovih autora. Uzimajući u obzir, pri tome, koliko je putovanje za njih bilo i važna biografska činjenica. Tako je postalo jasno da je doživljaj neke zemlje uvek već posredovan literaturom. I na kraju, implicitno, a na osnovu datih primera, jedno drugačije i šire shvatanje putopisa, odnosno putopisnog. Autor smatra da dosadašnji pristupi, kao što su naratologija, iterologija ili kultura putovanja, i njemu, nešto bliži, tzv. diskurs putovanja nisu iscrpljivali sve mogućnosti putopisa. Takođe, smatra da treba govoriti o putopisnom, onako kako se govori o romanesknom, poetskom ili fikcionalnom. Dakle, treba krenuti od atributa, tj. kvaliteta, i naglasiti da je putopis imanentno intertekstualni žanr.

\section{Putovanje i pisanje}

Izbor pisaca nije slučajan: Gete i Stendal su putopisni kanoni, a Crnjanski u svom značajnom putopisu Ljubav u Toskani dovodi u pitanje književnu sliku Italije, ali je ipak na neki način potvrđuje. To pak ne znači da je Bajron izabran samo kao „engleski predstavnik“- mada smo svakako imali na umu ne samo pojedine pisce/putopise nego i njihove putopisne tradicije, u krajnjem slučaju njihov odnos prema nacionalnoj

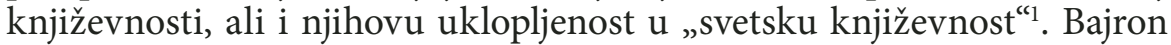
je izabran iz nekoliko razloga: savremenik je Getea i Stendala koje sreće u Italiji. Drugo: čitanje IV pevanja Čajlda Harolda, paralelno sa pismima i dnevnicima vođenim za vreme sedmogodišnjeg boravka u Italiji, pokazuju da je ne samo pisanje o Italiji, nego i življenje u njoj pod naročitim uticajem pročitane literature.

Kao što je već primećeno, putopis je vrlo često nadnacionalan, putopisni uzori su češće strani, a manje „domaći“, osim toga putopis je mesto ukrštanja domaćeg sa stranim, ulazak u „svetsko“. Svetsko, univerzalno ili, na izvestan način, kanonsko ambivalentno je, nestabilno. Najpozitivniji smisao bio bi u nekoj vrsti prosvetiteljskog kosmopolitiz-

1 Nije slučajno što baš Gete govori o „svetskoj književnosti“. 
ma, „uspostavljanja dijaloga“, „usvajanja pozitivnog drugog/drugačijeg”. No, sporan je kao što to sami putopisci na izvestan način pokazuju, a što je postalo naročito mesto kritike u XX veku, njegov „logocentrizam”, odnosno evrocentrizam. Mi smo ovde u naročitoj prilici da otkrivamo i posmatramo načine nastanka i prenošenja stereotipnih, ambivalentnih „kolektivnih predstava“, pošto je Italija kao naslednica Rimskog carstva, centar zapadnog hrišćanstva, a kasnije i zahvaljujući „renesansnom procvatu" bila izvoznik ideja, od vrlo banalnih: modnih i kulinarskih, do vrlo ozbiljnih: teoloških, političkih, naučnih, umetničkih. Pošto će ovde uglavnom biti reč o putopisima iz XIX i XX veka, odnos prema Italiji će često biti još „složeniji”. Tako ćemo govoriti, pre svega, o jednoj idealizovanoj, pomalo nestabilnoj i u svakom slučaju dominantnoj slici Italije. O jednom toposu Italije koji svoje mesto pronalazi i izvan putopisa, recimo, u Burghartovoj Kulturi renesanse u Italiji, Tenovoj čuvenoj Filozofiji umetnosti, zatim u neobičnoj knjizi F. Ničea Vesela nauka, pa onda opet $\mathrm{u}$ ličnim beleškama s putovanja Frojda i Junga, i možda, pomalo neočekivano, u De Sadovoj Juliji. Očigledno je da su pomenute knjige pod uticajem putopisne literature, i da sve one, na neki način, imaju nečeg putopisnog. Međutim, ono što je manje poznato je da je ne samo Ten pisac putopisa o Italiji, nego su to na izvestan način i Burkhart i De Sad. Burkhartova knjiga Čičerone: uvod u uživanje u umetničkim delima Italije ${ }^{2}$, objavljena je pet godina pre Kulture renesanse (1860). Čičerone je po svom sadržaju više teorijska knjiga: govori se isključivo o umetničkim delima stručnim jezikom, međutim, sam naslov, ali i način izlaganja: ne hronološki ili stilsko-poetički nego po mestu gde se nalaze: mesto u gradu, ako je reč o arhitekturi, odnosno mesto u muzeju, ako je reč o likovnim delima, pa i ton izlaganja (ponešto usmeni) ostaju putopisni. Sadovo Putovanje u Italiju (Voyage d'Italy) objavljeno je mnogo kasnije, tek 1967, i u kontrastu je sa njegovom slikom Italije iz Julije. U putopisu se pojavljuje kao „prosvetiteljski“ putopisac pun predrasuda, a za Napulj tvrdi da je „najlepše mesto nastanjeno degradiranim vrstama“" (prema Moe 2002: 63).

U načinu na koji Crnjanski transformiše putopisno ili čak pre dekonstruiše, postaje sasvim očigledno koliko je putopis naglašeno intertekstualni žanr. Ako se pozovemo na poznatu „književnu svađu“ oko toga da li je za pisanje ljubavne pesme presudnije ljubavno ili čitalačko iskustvo, mogli bismo (ironično) primetiti da su za pisanje putopisa ne samo neophodna oba iskustva, nego se ona na različite načine moraju eksplicirati, odnosno potvrditi koliko u tekstu, toliko u samoj stvarnosti, osim, naravno, kada je reč o fantastičnom putopisu. Intertekstualnost može biti i glavna strategija pisanja, može biti i način na koji se obezbeđuje pripadnost nekoj tradiciji ili grupi ili način na koje se pojedine tradicije i grupe demistifikuju (parodija), neka vrsta riznice znanja i postupaka, vrlo često i oblik autocitatnosti: kasnije pisanje na osnovu svojih beležaka, dnevnika ili izravno prerastanje beležaka u putopis, i svakako najbanalnije:

2 Burkhart 2006. 
podrazumeva da ste se ponešto raspitivali o mestu na koje putujete, pa ćete u skladu sa vašim interesovanjima dobiti i različita usmena i pismena obaveštenja. Takođe se podrazumeva da ćete imati i različite vrste vodiča. Koliko god da su govorni žanrovi važni za putopis ${ }^{3}$, za upoznavanje sa stranim, nema sumnje da je pozivanje na govorne žanrove ređe, a njihovo korišćenje još ređe i donekle ima status „trača” ili „informacije za kako se snaći"4 za razliku od književnih, kulturnih, putopisnih autoriteta, odnosno njihovih tekstova. Postoji neka vrsta opšte tradicije, neka vrsta nacionalne tradicije, neka vrsta lične tradicije. Važno je napomenuti da u putopisnu tradiciju ne spadaju samo putopisne knjige ili različita naučna (ili popularna) literatura o toj zemlji, nego su vrlo važni i sami pisci te zemlje, način na koji su oni sami sebe videli. Kad je reč o Italiji, najvažniji je Dante, ponekad Petrarka, češće Bokačo i Bandelo, Makijaveli, ponekad Goldoni i Taso. Od Stendala, pa naovamo, i Kazanova. Krajem XIX veka i Leopardi. U nekim slučajevima su to i rimski pesnici: Ovidije, Propercije, Horacije. Naročito su važni „hroničari”, koji se nekad čitaju književno, a nekad naučno: Tacit - Anali, Vilani i Dino Kampanja - Hronike, ponovo Makijaveli - Istorija, ali i Seneka - Pisma prijatelju.

Treba napomenuti, pošto je presudno za razumevanje Crnjanskog, da je naša tradicija putopisanja, prema rečima Olge Stuparević, u najvećoj meri didaktična (1976: 72). Naravno, ako uzmemo u obzir samo književno vredne putopise, slika je nešto drugačija. Međutim, ono što je očigledno je da je čak i za najbolje pisce karakteristično „ugledanje na druge“, „,viđenje tuđim očima“, čak i vrlo „zaslepljeno“. Ali kao što ćemo videti, to ne važi samo za naš putopis, i pre je pravilo nego izuzetak. „Viđenje tuđim očima” problematično je samo onda kad je reč ne o usvajanju ili transformaciji, nego kad je reč o (potpunoj) identifikaciji sa drugim, ili bolje rečeno sa stranim kod drugog, što za posledicu ima idolopoklonstvo ili imitiranje. U ostalim slučajevima, izvor je stalne napetosti, ambivalentnosti slike, diskursa.

Dakle, ovde će „slika” i „putopis” imati ponekad i nešto šira značenja. To znači kad kažemo „slika” ne ograničavamo se samo na imagološki pristup, pre nas zanimaju različite „označiteljske prakse”, način konstruisanja neke tačke gledišta ili određenog diskursa. Takođe, čini nam se da je reči „slika” inherentna neka vrsta statičnosti, modelovanosti, stabilnosti, što naravno ne znači da nema protivrečnih i nestabilnih slika, nego se pre misli na neku vrstu formalne naglašenosti, „signalizovanosti“. Recimo, na onu vrstu razlike koja postoji između reči-simbola, reči-metafore i reči-znaka. Nema sumnje da je „slika”, bar što se književnosti tiče, uvek neka vrsta toposa, pa makar i ne bila opšte mesto u smislu opštepoznatosti njenog značenja, nego u načinu na koji se konstruiše/proizvodi. Nas svakako zanimaju toposi, ali i pitanje kako neka slika ili diskurzivna praksa postaje topos, ili zašto ne postaje, kako u različitim žanrovima, u različitim poetikama, kod različitih pisaca one menjaju neka svoja znače-

3 Čičerone je vodič stranaca koji pokazuje znamenitosti.

4 Toga ima najviše kod Getea. 
nja, u krajnjem slučaju i zašto, i kakva je njihova funkcija. Takođe, „putopis" nešto šire razumemo, pre svega u značenju putopisno. Putopisno određujemo kao diskurs koji proističe iz stvarnog postojanja jednog ja koje putuje (to znači da odlazak iz A u B uglavnom podrazumeva i povratak u A, mada to nije presudno) i koje piše o tom putovanju. Postoje različite prakse pisanja: dokumentarna, realistička, romantičarska, autobiografska, itd., kao što postoji i mogućnost uključivanja putopisnog u neki nad-žanr / diskurs, što nije redak slučaj: najčešći slučaj je uključivanje u memoare ili autobiografiju, ali nisu retki ni primeri uključivanja u tzv. fikcionalne žanrove ili, kao što smo videli, čak i u naučne žanrove. U tom smislu, zanimljiviji su još slučajevi Gibona i Monteskjea koji označavaju prelaz sa putopisnog znanja na naučno. Gibon je poznat po svojoj studiji Opadanje i propast Rimskog carstva, u celosti objavljenoj 1788. Ono što je manje poznato su njegovi posthumno objavljeni Memoari, odnosno u njima opisani boravak u Rimu: „...Sedeo sam i zadubljeno posmatrao ruševine Kapitola, i dok su bosonogi monasi pevali večernju molitvu u Jupiterovom hramu, prvi put mi je palo na pamet da pišem o opadanju i propasti grada“" (prema Churchill 1993: 8). To što je Italija inspiracija nije ni u njegovo vreme bilo ništa novo. Monteskje je pre njega napisao svoja Razmatranja o uzrocima veličine Rimljana i njihove propasti (1734), ali je takođe bio i pisac za putopis važne knjige: Duh zakona (1748). Ono što je manje poznato je da je i pisac, posthumno objavljenih Beležaka sa putovanja, ali i traktata Razmišljanja o stanovnicima Rima (1732), koji je napisan tokom putovanja. Da je za nastanak njegove antropogeografske teorije bio presudan boravak u Rimu misli i Šeklton (Shackelton), ali on dalje izdvaja i teorijske uzore: Hipokrata, Žana Bodena, Espiar(d)a (François- Ignace Espiard) (Shackelton 1955). I zapravo, čitav XIX i XX vek pretvaraju putopisna znanja u teorijska: recimo Tenov determinizam (rasa, sredina, momenat) duguje mnogo madam de Stal i Stendalu. Zatim, sa Lisjenom Fevrom i francuskom novom istorijom čitava istorija dobija "privatnu”, ali i kulturnu dimenziju. Studije kulture se zapravo (interdisciplinaran pristup) bave onim što je bilo predmet putopisa: fenomeni kulture, problem identiteta, itd. Mi se ovde služimo i „materijalom” koji ne samo da nije bio zamišljen kao „putopis” nego nije ni pisan za objavljivanje, kao što je to slučaj sa Bajronom ili Gogoljem. Ovaj, nešto širi uvod, bavljenje piscima/ pisanjima koji nisu predmet detaljnijeg razmatranja, služe kao pozadina/ kontekst u kojoj će „glavni pisci“ biti razmatrani.

Postojanje tradicije putovanja/ pisanja o Italiji je sasvim očigledno i ono ima svoje srednjovekovne korene, no budući da su za taj period bila karakteristična hodočasnička putovanja, tek renesansa, da tako kažemo, sekularizuje putovanje. Stvaranje trgovačkih gradova, pa i industrijskih u Italiji, Holandiji, Flandriji, donekle u Engleskoj, Nemačkoj i Francuskoj, znatno smanjenje moći sveštenstva i plemstva, uvođenje novih znanja i veština, imaće za posledicu i drugačiji položaj subjekta i, kako bi to rekao Burkhart, u vezi sa rađanjem autobiografskog žanra u renesansi, „poja- 
vu nove subjektivnosti”. Recimo, najstarije tradicije su svakako Engleska i Francuska. No, valjalo bi biti oprezan. Engleska književnost / istorija književnosti najviše je pažnje polagala upravo stvaranju same tradicije: zaslužni su za uvođenje Grand Toura. Po Kadonovom saznanju, izraz je prvi upotrebio Ričard Lasels (Richard Lassels) u svom Putovanju u Italiju 1670. da bi njime označio uobičajeno putovanje Engleza koje je podrazumevalo obilazak nekoliko zemalja, a čiji su krajnji cilj bili Rim i Napulj (Cuddon 1999: 363-364). Tradicija putovanja je u Laselsovo vreme stara bar dva, tri veka i bila je neka vrsta obrazovnog putovanja engleskog plemstva koje se učilo dvorskom ponašanju, veštinama, a koji su kasnije dobili i prave teoretičare: Makijavelija (Vladalac) i Baltasara Kastiljonea (Dvoranin). Sami engleski pisci su izrazito tradicionalni, ali zato i najizrazitiji antitradicionalisti: najpoznatiji je svakako Stern, dobar primer je i Midlmarč Džordž Eliot u kom se baš ruga Grand Touru, a tako bi se moglo razumeti i Bajronovo odbijanje da piše „pravi“ putopis o Italiji. Bajron navodi dva razloga: sva mesta su već opisana i to veoma verno, intimno je vezan za mnoge italijanske porodice i to bi značilo izigrati njihovo poverenje. „Izigravanje poverenja” potiče od italijanske ogorčenosti načinom na koji su predstavljani, a sigurno je zbog toga u jednom trenutku, kao što Stendal kaže, došlo do izrazitog nepoverenja, pa možda nekad i do mržnje prema strancima. Za Sentimentalno putovanje po Francuskoj i Italiji Lorensa Sterna moglo bi se reći da je neka vrsta antiputopisa: parodira se u to vreme popularan istoimeni putopis T. Smoleta ${ }^{5}$, put i pisanje o putu nemaju više veze sa znanjem nego s osećanjem. „To je mirno putovanje srca u potrazi za prirodom, i za onim utiscima koji proističu iz nje i koja nas navode da volimo jedan drugog, i ceo svet, više nego što ih volimo" (Stern 1963: 92). Sternovo razumevanje sentimentalnog važno je zbog otvaranja prostora za subjektivno i pisanje „unutrašnjeg pejzaža“. Zatim, upotrebljava parodičnu autocitatnost - predstavlja se kao Jorik (Tristram Śendi), ali i parodičnu citatnost: Jorik „kraljevska dvorska luda“ (Hamlet) - kad traži pasoš. Jasno je da putopis tako postaje i fikcionalan ili autofikcionalan. Još: osim „natuknice“, stvarne ili izmišljene o susretu sa Smoletom u Torinu, Italije u putopisu nema. Ovo bi trebalo ubrojati u „postupak“, što, koliko nam je poznato, nije urađeno, i umesto uobičajenih razloga koji se navode da su ga sprečili u pisanju/objavljivanju putopisa o Italiji govoriti o „minus prisustvu“ putopisne Italije, odnosno razumeti to kao: „Italije iz putopisa i nema“" Koliko je engleska tradicija bila živa svedoči i raširenost stereotipa „Englez u Italiji”: u XVIII veku, prema svedočenju Getea, venecijanska (komična) pozorišta bila su preplavljena komadima na tu temu (Gete 1962: 152).

5 Smolet je bio imresioniran italijanskom umetnošću, ali se sve vreme žalio na italijansku, ali i francusku neurednost, negostoljubivost, lenjost i uopšte na način na koji funkcioniše društveni život u tim zemljama.

6 Polemika oko Grand Toura zaoštrava se sredinom XVIII veka: najoštriji su članci u Džentlmens magazinu, najpoznatija je Lokova studija (Esej o obrazovanju) (Bohls and Duncan 2005: 13-18). 
Francuska tradicija je manje koherentna, uostalom njihove političko-verske-kulturne veze s Italijom su čvršće: oni su u pojedinim trenucima bili vladari u Italiji (Sijena je u XV veku bila francuska; za vreme Napoleona - kad i Stendal prvi put boravi u Italiji), pa su stoga i lične veze mnogo brojnije. Za nas je ovde važno nekoliko imena: Žan i Žoašen Di Bele. Prvi kardinal koji službeno boravi u Rimu, drugi njegov siromašni rođak, pesnik Plejade, koji u Rimu piše Rimske elegije, ali se inspiriše i za Odbranu francuskog jezika, i treći u tom neobičnom društvu: Rable, franjevac i kardinalov lični lekar. Blez de Monlik pisac čuvenih Memoara, vođa sijenske vojske za vreme firentinsko-španske opsade. Zatim Montenj, Filip de Komin, uvaženi diplomata i pisac Memoara, još: De Bros ${ }^{7}$, Šatobrijan, Renan, Ten, Burže i Moris Bares. Za ilustraciju francuskog odnosa prema Italiji (Francuzi su, za razliku od ostalih, teško prihvatali "prvenstvo Italije" čak i u srednjem veku i renesansi, a već su od XVI veka sebi eksplicitno pripisivali ulogu „lučonoša civilizacije“), poslužiće jedan anegdotičan primer iz istorije. Naime, krajem XV veka pojavila se u Napulju nova bolest, sifilis, a pošto su simptomi i tok bolesti prvi put tačno zapaženi, praćeni među francuskim vojnicima koji su u tom trenutku bili u opsadi Napulja, bolest je nazvana „morbus galicus”. Ni Francuzi nisu ostali dužni: njihov naziv bio je "mal de Naples" (napuljska bolest) ili kasnije, kad su i same pape bile zaražene, „rimska bolest”. I to je verovatno jedan od razloga zašto je u putopisnoj literaturi atribut „razvratni” neodvojiv od Napulja. „Osvajanje” i „nadevanje imena” našli su mesto, kako je i red, u Volterovim satiričnim stihovima:

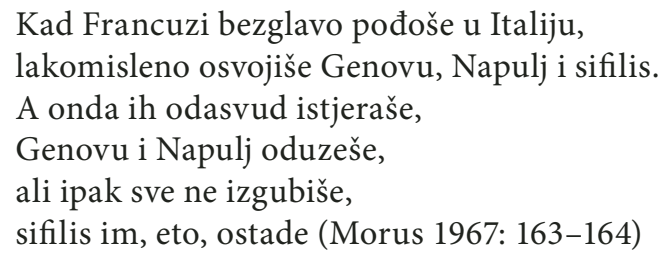

I to su, u stvari, skoro jedini slučajevi u kojima Francuzi priznaju da su se ugledali na druge. Tako De Sadova Julija, glavna junakinja istoimenog romana („zla sestra”) sa svojim razvratnim društvom putuje u Italiju, a najokrutnije i najperverznije scene dešavaju se na papskom i napuljskom dvoru. S tim što „rimsko-napuljska bludnost” ima svoje korene u antici: ostrvo Kapri poznato je po Tiberijevim orgijama i smaknućima, grad Baja slovi za „luku razvrata”, čemu treba dodati Neronovu svirepost i „vile za uživanje" u Pompeji. Upravo, otkrivanje Pompeje i Herkulanuma zaslužno je ne samo za „popularisanje" antičke umetnosti, mitoloških motiva, za izučavanje Vezuva nego i „okrutnog sladostrašća”. Tako bismo, zlobno, mogli, imajući na umu De Sada, mada ne s punim pravom - on je samo najpoznatiji, odgovoriti Francuzima da su i u ovome nadmašili ostale: dali su čitavu filozofiju, apoteozu, odbranu okrutnoj samodovoljnosti.

7 Važan zbog Stendala koji je bio priređivač njegovih pisama koja su tek posmrtno objavljena, a koja su pisana privatnim licima. Takođe ga spominje i Crnjanski. 
Nema sumnje da su i ostale tradicije žive i važne, no njihova važnost često ne prelazi nacionalne granice. $\mathrm{O}$ nemačkoj tradiciji znamo nešto zahvaljujući Vinkelmanu, Geteu, Hajneu i Manu. ${ }^{8}$ Ruska književnost je bila predmet našeg interesovanja samo zato što je Crnjanski „insistirao“ na njoj u svom putopisu, pa se onda pokazalo da njegovo viđenje nije bez osnova. Pošto će Dostojevski i Gogolj biti spomenuti u tom kontekstu, zanimljivo bi za nas bilo još: boravak Lu Andreas Salome u Italiji i njeno poznanstvo sa Ničeom u isto vreme i neobična „zaljubljenost u Italiju” Vjačeslava Ivanova. No, to su predmeti za dalje istraživanje. I tek da spomenemo, što se španske književnosti tiče, šire je poznat jedino Kalderonov, takođe, ratni, osvajački boravak i beleške.

Kao što smo videli razlozi putovanja često su bili različiti, recimo, Bajron i ̌̌eli su prognanici i Italija postaje neka vrsta nove domovine, što je još drastičniji slučaj sa Stendalom. Osim tzv. obrazovnih putovanja, i pre stava: da je svako pisanje o Italiji na neki način obrazovno (i oni koji su došli kao osvajači i izašli kao pobednici pretrpeli su kulturnu asimilaciju, mada su verovatno bili zaslužni i za uvođenje nekih svojih običaja) važna su spomenuta hodočasnička putovanja i to, pre svega, u Rim i Asizi, a krajem XVIII veka postaje popularno i bračno putovanje, moda za koju su, opet, zaslužni Englezi. Svadbeno putovanje našlo je svoje mesto i u Floberovom Rečniku otrcanih misli: „Mora se videti odmah posle venčanja. Izaziva mnoga razočaranja. Nije tako lepa kao što se priča" (1964: 298). Možda bi pre trebalo govoriti o posećenim mestima pošto je svako od njih vezano za drugačiju tradiciju: Rim - latinski, papski, barokni, Firenca - bankarska, medičijevska, Danteova, Mikelanđelova, renesansna i nasuprot njoj: Sijena - trgovačka, srednjovekovna, „ćaknuta“, Venecija - trgovačka, bonvivanska, pozorišna, Kazanovina, Napulj - razvratni i španski.

\section{„I ja u Arkadiji”}

Citirani podnaslov Geteovog Putovanja po Italiji nagoveštava idealnu sliku Italije. No, predistorija idiličnog hronotopa mnogo je duža i zanimljivija nego što to na prvi pogled izgleda. Prema rečima B. Živojinovića datim u objašnjenju, moto potiče iz latinske književnosti, a Nikola Pusen ga koristi kao natpis na dve svoje slike i on u tom obliku stiže do Herdera, Vilanda i Šilera (Gete 1962: 413). Nema sumnje da je reč i o nekoj vrsti privatne poruke: naime, Putovanje po Italiji (1816) zamišljeno je kao nastavak autobiografije Poezija i stvarnost i pisano je skoro tri decenije posle boravka u Italiji, dok se Drugi boravak u Rimu (1829) smatra posebnim delom. Putovanje bi bilo neka vrsta stilizovanog dnevnika i pisama upućenih uglavnom Herderu i g-đi fon Štajn za vreme boravka u Italiji. Ako uz to dodamo da je i Geteov otac putovao u Italiju 1740. i da je sačuvan i njegov dnevnik s putovanja, pri čemu sam Gete napominje da mu je „ljubav pre-

8 Svakako ne bi bilo bez osnova ni uključivanje Direra u tu tradiciju, kao što to Crnjanski na izvestan način i čini. 
ma Italiji" preneo otac, postaje jasnije kako dolazi do intimnog doživljaja (književnog) opšteg mesta, a koji ga resemantizovanog vraća ponovo u književnost. Dakle, otac, g-đa fon Stajn, Herder, Viland, bili su duhovni uzori, ova dvojica i književni ${ }^{9}$ i „, ja u Italiji” ima obredno značenje: omogućava „inicijaciju” u dato društvo. Kasnije žanrovsko i stilsko uobličavanje uslovljeni su „intimnim doživljajem”, pa ga zato i čuvaju: obrazovno putovanje - inicijacija u opštu (zapadnoevropsku) kulturu, Künstlerroman - otkrivanje i potvrđivanje sebe kao pesnika (Gete tek u Italiji odustaje od bavljenja slikarstvom), i iz mnogo drugih razloga (ljubavni preobražaj nije manje važan) prelomni trenutak u životu. Ovaj, po Geteovim rečima: salto mortale ponovo potvrđuje vezu između književnosti i života i vraća nas na početak. Doslovno značenje salto mortale-a odnosi se samo na akrobatski skok, prenesena značenja su „očajnički korak” i „sudbonosan preokret”(Klaić 1966: 1095). Spoj smrti i rođenja, koji tematizuje renesansa, a Gete oličava u svom „duhovnom preporodu”: „Preporod koji me iznutra preoblikuje neprestano deluje” (Gete 1962: 207) potvrđuje se dvostruko. „I ja u Arkadiji” ili izvorno „Et in Arcadia ego”, potiče iz poznosrednjovekovnih tekstova, a izgovara je Smrt (RKT: 47-48). Srednjovekovni podtekst se još jednom pojavljuje: arkadska priroda Italije potvrđuje se konačno na Siciliji. Naravno da je Sicilija kao grčki locus amoenus, prepoznatljivija, ali ne treba zaboraviti ni srednjovekovnu (imaginarnu) geografiju: upravo se na Siciliji nalazi raj. ${ }^{10}$ Stoga Geteova tvrdnja: da se tek na Siciliji „nalazi ključ za sve” (Gete 1962: 313) mora se u tom kontekstu i interpretirati. Međutim, ne treba zaboraviti ovde ni Vinkelmana i, po Moevom mišljenju (Moe), uticaj barona Ridezela (Riedesel) (2002: 57) ${ }^{11}$. A uobičajeno, ne samo popularno nego i „naučno” mišljenje bilo je da je Firenca „ključ za sve". Nije potrebno naročito objašnjavati razloge: renesansa, tj. racionalnost, novi oblik uređenja (komuna), rađanje političkih partija i institucija, novi oblik ratovanja i stvaranje profesionalne vojske, trgovina, i pre svega bankarstvo, umetnost, nauka i Medičijevi. I doista, to su postale suštinske odrednice zapadne kulture. Geteov povratak antici mogao bi se razumeti i kao poetički: poznato je da ga određuju i kao neoklasicistu. Dakle, njihovo mišljenje bilo bi da renesansa i klasicizam nisu na pravi način razumeli antičku klasiku. A antička klasika za njega, ali i ne samo njega, ima značenje koje je on pridavao pra-biljci koju je tako uporno tražio, a za koju je smatrao da je prva biljka iz koje su nastale sve ostale. Međutim, koliko god da je bio „pristalica Homera”, očigledno je u mnogo čemu da njegovo shvatanje klasike ostaje „rimsko”. Upravo se kod Vergilija, u Eklogama, prvi put pojavljuje Arkadija, umesto Sicilije, a „Večni grad” je naravno Rim. Ovakvo razrešenje: „Desilo se ono što sam uvek govorio sebi: naime, da ću tek

9 Gete kreće na put u toku svoje „vajmarske faze” kojoj prethodi Sturm und Drang faza (Herder, Viland), a posle putovanja sledi „vajmarska klasika” i njegovo „druženje” sa Šilerom. Dakle, upućivanje na Šilera dešava se za vreme pisanja, a ne putovanja.

10 Ovakvo geografsko smeštanje raja pronalazimo kod A. Gureviča (1987: 214).

11 Ridezel je autor Putovanja kroz Siciliju i Veliku Grčku (1771), „u formi pisama upućenih Vinkelmanu" koji mu je bio mentor i prijatelj, ali koji nije nikad bio na Siciliji (Moe 2002: 58). 
u ovoj zemlji naučiti da shvatam i objašnjavam mnoge prirodne fenomene i mnoge zbrke u mišljenjima" (Isto: 270), ima i svoje objašnjenje. Ako je Italija ključ, onda je donekle logično Geteovo odbacivanje istorije, svojih, a tuđih znanja, potreba da se naučeno revalorizuje viđenim, doživljenim. „Meni su sad važni čulni utisci, koje ne može dati nikakva knjiga, nikakva slika" (Isto: 79). Ali to pre svega označava prelazak sa romantizma (Strurm und Drang) na klasicistički realizam. Ako sa „klasicističkim realizmom” moramo biti pažljivi jer je konstruisan spajanjem različitih perspektiva, onda sa Geteovim „romantizmom” moramo biti još pažljiviji jer mogao bi se odnositi na mnogo šta, ili skoro ni na šta. A načelna razlika među njima nije poetička, nego je epistemološka: promena fukoovski shvaćene episte$m e$ i eventualno metoda subjektivno-objektivno, iracionalno-racionalno, od uosećavanja do fenomenologije. Nesumnjivo je da je priroda glavni predmet njegovog interesovanja. Odnos prema prirodi: doživljaj, opis, klasifikacija i odnos kultura- priroda suštinski su za razumevanje njegovog putopisa, i on u tome ostaje sasvim u duhu prosvetiteljstva. Ako je za prvu fazu karakterističnija "divlja” ili „netaknuta priroda”, „natprirodna", nadmoćna priroda, onda bi za drugu bila karakteristična "uređena”, "kultivisana" ili pre prema određenim slikama i knjigama "strukturirana” priroda. Očigledan je uticaj Linea na njega, ali i francuske materijalističke filozofije (pre svih Holbaha). Za takvu Italiju imanentni su opisi prirode i razmišljanja o umetnosti, pri čemu u duhu klasicističke estetike, umetnost uvek, na neki način, podražava prirodu. „Što se tiče Homera kao da mi je pala mrena sa očiju. Opisi, poređenja itd, izgledaju nam poetski, a ipak su neizrecivo prirodni; istina, izvedeni su sa takvom čistotom i snagom da se čovek uplaši"'(Isto: 251). U osnovi ovog klasicističkog načela krije se jedno starije, srednjovekovno shvatanje prirode kao knjige. „Laičku predstavu o svetu kao knjizi dao je u XIV veku u Nemačkoj Konrad od Megenberga (1309-1374), koji je 1350. na nemački preveo enciklopediju Dominikanca Tome iz Kantemprea (Thomas de Cantimpre, De naturis rerum [O prirodi], napisana između 1228. i 1244. godine) i to pod naslovom "Buch der Natur” (Knjiga prirode)" (Kurcijus 1996: 525).

Od literature koju čita izdvojićemo: Folkmana, pisca knjige o Italiji, Ferbera, pisca Pisama iz Italije - o prirodnim znamenitostima ove zemlje, Andrea Paladija, najpoznatijeg klasicističkog arhitektu i pisca Četiri knjige o arhitekturi, i Vinkelmana. Čitanje Vinkelmana biće predmet poruge kod Stendala, Buržea i Crnjanskog. Stendal je ime izabrano s očiglednom namerom da se naruga klasicistikom ukusu Vinkelmana i Getea. Stendal je mesto Vinkelmanovog rođenja, a pošto geografski dodaci imenu imaju veze s nekom titulom, ovde barona, ispada da je Vinkelman bio Stendalov kmet $^{12}$. U Vinkelmanovoj zadivljenosti ruševinama kriju se „klice“ kasnije romantičarsko-naturalističke estetike nakaznog, ljubavi

12 Ovakvo poreklo imena nalazimo i kod Ilje Erenburga (1965: 158), dok se Ž. Starobinski više bavio pseudonimima i Stendalovom potrebom za maskom (2004). Ljubavna imena, u ogledu O ljubavi, ali i u (privatnim) ljubavnim pismima, italijanskog su porekla, ili bar italijanizovana: Dominik, Salvijati. Koren ove „igre“ je u bežanju od oca, „buržoaskog“. 
prema smrti, grobljima koja će svoj vrhunac, bar što se Italije tiče, dostići u delima Morisa Baresa i D’Anuncija, a koji se sasvim lako prepoznaje i u Smrti u Veneciji (1911) Tomasa Mana. Treba ipak dodati da je za takvu modu bio važan i možda čak i presudan uticaj De Sada. Ne samo da se takva estetika iščitavala iz njegovih romana, nego se u Juliji pokazuje da „obrazovanje za porok“ takođe vodi u Italiju, pri čemu se samo donekle razlikuju posećana mesta: Rim, Napulj, Kapri, Baja. Zanimljivo je, a Mek Kalam je to pokazao, da je i De Sad pod uticajem Vinkelmana. De Sad boravi u Napulju osam godina posle Vinkelmanove smrti, i o Vinkelmanu „sluša“ od libertena Godara (Goudar). Inače, Vinkelman je bio homoseksualac i spominje ga Kazanova u svojim Memoarima (McCallam 2009: 260). Burže i Crnjanski će ga kritikovati na osnovu sledećeg izvoda: „Kad je reč o stubovima uopšte, treba još primetiti da je najstarija građevina starih u Italiji, čiji stubovi imaju, svaki za sebe, poseban pijedestal, jedan stari hram u Umbriji“" (Vinkelman 1996: 39). Zbog čega Gete u Asiziju ne obilazi ono što je u njemu najprepoznatljivije, bazilike Svetog Franje. „S leve strane sam, s osećanjem nelagodnosti, ostavio ogromne temelje crkava vavilonski naređanih jedna nad drugom, gde počiva sveti Franja; jer govorio sam sebi da se u njima žigošu glave kao što je ona u mog kapetana" (Gete 1962: 172). „Gete, taj protivnik srednjega vijeka i tako odlučan, te došavši u ovaj grad Asiški ne htjede tu gledati ništa do jako neznatnih ostataka hrama Minervina ..." (Bourget 1923: 136) „Sam veliki gospodin, ministar vajmarski, pisac Ifigenije, popeo se dovde, na svome putovanju i proveo, duboko zamišljen, nekoliko časova, pred ovim jedinim antičkim ostatkom (Minervinim hramom - Z. B.), u ovom gradiću siromaštva i ševa (Crnjanski 1995:136). Svako od dva ili tri spominjanja Getea u Ljubavi u Toskani je ironično. Uvek se uz njegovo ime nađe i neka titula, osim toga, kritika je uvek i intertekstualna, kao što ćemo još videti kad budemo pisali o Stendalu.

\section{„Kriva bi knjiga i ko je napisa”}

Bajron je u Italiji živeo od 1816. do 1823. A nekih desetak-petnaest godina pre toga bio na kraćem putovanju. Proveo je otprilike po dve godine u Veneciji, Raveni i Pizi, i nešto kratko, po Šelijevoj smrti, do odlaska u Grčku, u Đenovi. Boravak u Italiji dolazi posle njegovog razvoda od Izabele Milnbek, i „izopštenja“ iz engleskog društva, te tako Italija postaje druga domovina. Boravak u Italiji obeležava nekoliko ozbiljnih ljubavnih veza, pre svih sa Kler Klermont, polusestrom Meri Šeli, i Italijankom Terezom Gvičoli, i brojne usputne. I nekoliko dela: Bepo, Četvrto pevanje Čajlda Harolda, Don Žuan. Osim toga, piše pisma i memoare koji će posle njegove smrti biti spaljeni. Povod za pisanje mu je otkrivanje istine o sebi. Iz više razloga, odbija da piše putopis o Italiji. Većina posećenih mesta je već veoma verno opisana: „Sigurno ste pročitali mnogo opisa o njoj (Veneciji - Z. B.), i većina ih je verna. Ovo je poetično mesto, a za nas 
i klasično još od Šekspira i Otveja (Bajron 1985: 158), a što se Italije tiče kaže da je intimno vezan za mnoge italijanske porodice i da bi to značilo izigrati njihovo poverenje. Tako njegovu putopisnu Italiju iščitavamo iz Četvrtog pevanja Čajlda Harolda, i pisama upućenih prijateljima. Njegova slika Italije uobičajena je za putopis. Italijani su „deca sunca” i labavijeg morala. I pre svega:
„Italijo, čak i sad najlepša međ’ svima!
Oduvek si bila kao vrt u kom
Svih lepota prirodnih, umetničkih ima;
Čak i kad si pusta, ima l' premca njima.
(Bajron 2005: 152-153, stanca 26)
Zatim nešto što se smatra romantičarskim toposom o Italiji:
Rime, zemljo moja! Dušo koja patiš!
Privi sebi one što su srcem siročad,
Ti koja si mrtvih imperija mati.
(Bajron 2005: 169, stanca 78)

Treba napomenuti da je Čajld Harold ispevan u stancama, što je strofa italijanskog porekla. Ova slika je u duhu Gibona, i daleko od one iz Grand Toura (Churchill 1993: 38). I nezaobilazno, Italija je zemlja ljubavi, a amor „najlepša reč na najlepšem jeziku“ (Bajron 1985: 236).

Iz ovakve slike Italije progovara jedna od omiljenih Bajronovih knjiga Korina ili O Italiji, madam de Stal. Prema rečima samog Bajrona, to je knjiga u kojoj su on i Tereza razmenjivali ljubavna pisma, pošto je Tereza bila udata. Paradoksalno, ili bajronovski tragično, njih dvoje se rastaju baš kad su se izborili za ljubav. Korina je roman, Italija otelotvorena kao žena, a objavljena je 1807. Čita se i kao „feministička knjiga“ i kao interpretacija italijanskog društva, politike i karaktera. U skladu sa njenom ranijom i uticajnijom knjigom De la littérature dans ses rapports avec les institutions sociales, 1799 , i ovde se književnost i umetnost dovode u vezu sa društvenim institucijama, ali i geografijom. Tako imamo podelu na sever i jug, pri čemu je po njoj sever superiorniji, zbog svoje filozofije, a mi bismo dodali i protestantske etike, što naravno ne smatramo tačnim. "The Roman character, that miracle of national pride and political institutions, no longer existed. The inhabitants of Italy were disgusted with every conception of glory; they no longer believed in anything but sensual pleasure." (De Stal, prema Casillo 2006: 16) Po njoj, dekadencija se dešava posle renesanse, a za to je uglavnom „kriva“ kontrareformacija. Ona je, osim toga, zaslužna za uvođenje, ali i dalje širenje stereotipa, toposa, motiva: Koloseuma na mesečini, koje pronalazimo i kod Bajrona, a kasnije i Stendala. Od Stendalove kritike De Stalove, što ćemo videti kasnije, oštrija je Lafargova. I on kao Stendal hvali O književnosti, ali za opise pejzaža kaže: „... lepote prirode otkrila je tek posle jednog putovanja po Italiji, i naročito posle isprekidanih studija kantovske metafizike, 
koja je prenošena u Francusku da bi bila suprotstavljena materijalizmu, koji su činili odgovornim za zločine i užase Revolucije“. Zatim dodaje da se „u to doba javljalo oduševljenje za rađanje sunca i meseca i za lepote prirode“ (1950: 72).

Zanimljivo je spomenuti i njegov satirični spev Bepo, koji se bavi razlikama između engleskog i italijanskog mentaliteta. A čije tragove pronalazimo i u pismima. Tako on u Italiji beži od Engleza „zabezeknutih budala koje idu po gradu i blenu“ (Bajron 1985, 160).

Svojim savremenicima Bajron je bio mnogo zanimljiviji kao pisac i njegova se biografija i čitala iz njegovih fikcionalnih dela, pre svega iz Manfreda ${ }^{13}$. Stendal Bajrona smatra „ljupkim genijem "14, a kasnije se ponavlja i izoštrava kod Ničea i Gogolja u to da je Bajron zanimljiviji kao čovek nego kao pisac. I po njegovim ličnim doživljajima se pokazuje da je slika Italije ambivalentna: osim dobrih, dešavaju mu se i loše stvari, spomenuti razlaz sa Terezom, Šelijeva smrt, smrt ćerke rođene iz veze sa Kler Klermont, pod prismotrom je policije zbog pomoći karbonarima.

Crnjanski izbegava sve romantične topose Bajrona, srećemo ga kao čoveka koji je izgubio ćerku: „Spominje se engleski pesnik Bajron, koji je, iza ovih prozora, visokih i svetlih, ležao, bez sna, u jahaćem odelu. Šapćući gorkim i bludnim usnama ime Alegre" (Crnjanski 1995: 57). Scenu pronalazimo u Bajronovom pismu Džonu Mariju, 22. IV 1821 (Bajron 1985: 349). U drugom slučaju, reč je o Bajronu iz Čajlda Harolda, $\mathrm{u}$ trenutku kad se nalazi na Trazimenskom jezeru i čita Tit-Livijev opis bitke između Rimljana i Kartaginjana ${ }^{15}$ (Crnjanski 1995: 121), (Bajron 2005, 166-167).

\section{Arigo Bejl Milanac}

Ovde ćemo govoriti o dva Stendalova putopisa: Rim, Napulj i Firenca godine 1817, u dva izdanja koja se razlikuju, i o Šetnjama po Rimu. Za potrebe uopštavanja, može se reći da su oni esejističko-dnevnički; govori se o nekoj temi (putopisne teme su osamostaljene) u vezi sa nekim datumom. Tačnije, neki događaj ili anegdota iz života povod su za dalja razmatranja ili potvrda za iznete teorije. U tom smislu bi se moglo reći, naročito za prvi putopis, da je filozofski.

Njegovi putopisi su zamišljeni kao kritika tada vladajuće (romantičarske) estetike idealno lepog i napisa o Italiji Vinkelmana, madam de Stal i Getea koji imaju veze sa tumačenjem antičke umetnosti, ali i sa

13 Gete, povodom Manfreda, govori o Bajronovom psihološkom profilu, „rođen da sam sebe muči”, koji dolazi do izražaja i u njegovim delima jer su „ispovedna”; ženske likove iz speva dovodi u vezu sa stvarnim događajima iz Bajronovog ljubavnog života (Gete 1982: 58).

14 Kratko poglavlje u Rimu, Napulju, Firenci, posvećeno je susretu s Bajronom. Bajron se obojici zahvaljuje kratkim pismima (1986: 372 i 380).

15 Reč je o Drugom punskom ratu u kome Kartaginjane predvodi Hanibal. 
toposom Italije kao zemlje smrti, prirode i groblja. Za De Stalovu kaže da ima samo jednu dobru knjigu „Duh društvenih zakona“, „inače, ona je u lepom i efektnom stilu beležila ideje koje bi čula od drugih u svom salonu“ (Stendhal 1957b: 137). Slika Koloseuma na mesečini, čiji je izvor De Stalova, kod Stendala će nešto drugačije izgledati. Umesto melanholije uživanje, i čitanje sto četrdesete stance Čajlda Harolda u kojoj je tematizovana gladijatorska borba u Koloseumu. Kritika Getea nije ništa manje oštra:

Nemci imaju samo jednog čoveka, Šilera, i dve knjige od vrednosti između dvadeset Geteovih tomova. Geteovu autobiografiju ${ }^{16}$ ljudi će čitati da bi uživali u izvanrednoj komičnosti čoveka koji sebe smatra dovoljno važnim da bi nam saopštio, u četiri knjige in $8^{\circ}$, kako se češljao u dvadesetoj godini i da je imao pratetku koja se zvala Anihen. (Isto: 207)

Ne jedanput reći će Stendal da i on ima ideal i to „prirode kao u ogledalu”. Ne treba naročito napominjati da on ne misli na podražavanje prirode kao Gete, već da je to proglas poetike realizma. Sa poetičke tačke gledišta, nije teško opisati razliku, no za nas je naročito zanimljivo kako do toga dolazi, šta dovodi do „promene mišljenja”? Pozivajući se na Filipa Amona (1990), možemo reći da on kao realisti piše „diskurs znanja”: iznosi činjenice, razmišlja o njihovoj tačnosti, iznosi teze, zastupa neke teorije, itd., pri čemu je osnovna da umetnost, odnosno čovek zavisi od društva (državno uređenje, običaji). Iako se poziva na klimu, reljef, uopšte pravi geografske razlike, pa i onu između severa i juga, govoreći o nacijama, kod njega ne nalazimo prirodu. Sve što se o njoj kaže svodi se na jednu, dve rečenice koje opisuju panoramu nekog mesta. Stendal je, kao što su već to njegovi prvi čitaoci primetili, a što se stalno ponavlja, slikar društva, odnosno „naravi i običaja“.

Svi putopisci opisuju samo italijanske stvari, njene spomenike, mesta, izvanredne prirodne lepote; a vi - rekoše mi - vi se trudite da koliko-toliko prikažete italijansko društvo, taj skup neobičnih običaja u vezi sa ljubavlju, strašću, samoćom, iskrenošću itd, iz koga se još ponekad iščaure veliki ljudi, kao što su Kanova i Rosini (Stendhal 1957b: 119)

Zato su Italijani „narod rođen za lepo“ (Isto: 125), a Italija „zemlja čula“ (Isto: 158), i još izrazitije „zemlja sladostrašća“ (Isto: 330), u kojoj vlada „opšta dobroćudnost i prirodnost“ (Isto: 201). Još: Italijane krasi „jednostavnost izražavanja i postupaka“ (Isto: 139).

Stendal ne samo da „prepisuje“, kako je tvrdio Gete ${ }^{17}$ i ostali njegovi proučavaoci i kritičari, nego je takođe neko od koga se „prepisuje“. Evo nekoliko primera koji postaju putopisna opšta mesta: Firenca kao grad

16 Putovanje po Italiji je nastavak Geteove autobiografije.

17 „U mnogim mestima je zaista bio; za druga ume da koristi tradiciju, i uopšte ume mnogošta tuđe da prisvoji. On tako prevodi neka mesta iz mog Putovanja po Italiji i tvrdi da je tu pričicu čuo od neke 'markezine"“ (Stendhal 1957: 118). 
racionalnosti, lišena svih strasti, nasuprot Sijeni, pa i ostalim italijanskim gradovima (Isto: 167); savremeni Firentinci u suprotnosti sa slavnim likovima iz prošlosti (Isto: 163). Mržnja između gradova kao nasleđe iz srednjeg veka: „Svaka varoš duboko mrzi svoje susede i smrtno je omrznuta s njihove strane“ (Isto: 145, 206). Rim je „grad grobova“ (Isto: 348, 395) i „grad prošlosti“, ali i „čarobnih fontana“ (Isto: 369).

Može se reći da niko od Stendala nije imao obimniju literaturu. Međutim, u vezi s tim, u Šetnjama po Rimu nailazimo i na jedan (auto)ironijski iskaz: „U ovom putopisu neće, dakle, uopšte biti potrebne učenosti“ (Isto: 329). Skoro je neverovatno koliko je i šta je čitao, a koliko nam je poznato to je još uvek neproučeno. S izuzecima, neka su imena ostala u pamćenju samo zato što ih on spominje: Pjetro Veri (Istorija Milana), Đuzepe Gorani (Istorija italijanskih dvorova oko 1796), Lorenco Pinjoti (Istorija Toskane), Đuzepe Mikali (Istorija antičkih naroda Italije). Ipak, najistinitije opise ne pronalazi u naučnim, nego u umetničkim delima, i to onima koja, kao i on, teže realističkoj slici sveta: u Bandelovim novelama, „u kojima se kao u nekom ogledalu vide naravi i običaji petnaestog veka" (Isto: 336). Iako sam tvrdi da umetnici nisu dobri kritičari, ni tumači: njima se sviđa samo ono što liči na njih, preporučuje čitanje Bandela koje leči „od predrasuda koje je mogao steći čitajući Sismondija, Botu i druge moderne istoričare" (Isto: 337 ).

Racionalista Stendal ima uplive iracionalnog. Tako je izgradio čitavu mitologiju oko svog italijanskog porekla, u Anriju Brilaru (fikcionalnoj autobiografiji; 1957a: 72), kad mu je teza da je „prava otadžbina ona u kojoj čovek nalazi najviše ljudi koji na njega liče" (Stendhal 1957b: 202) postala nedovoljna. I ima potpuno mistični doživljaj lepote u Santa Kročeu:

Pomisao da se nalazim u Firenci i blizina velikih ljudi čije sam grobove video ispunjavali su me nekom vrstom zanosa. Zadubljen u posmatranje uzvišene lepote, video sam je izbliza, dodirivao je takoreći. Bio sam dospeo do onog uzbuđenja gde se blažena osećanja koja pruža umetnost graniče s osećanjem strasti (Isto: 162)

A što je kasnije nazvano „Stendalovim sindromom“.

Jedini putopisi koje Crnjanski ne kritikuje su Stendalovi. „Jedini koji beše dostojan da piše o Italiji, i koji je još video baroknu, pozorišnu, ljubavnu Italiju, bio je Stendal“ (Crnjanski 1995: 63). „Neočekivana pobeda Stendalovog putopisa, njegove ampirske romantike, nedavno prošle, $\mathrm{u}$ ovim zabačenim varošima..." (Isto: 74-75)

Atributi Italije su zapravo Stendalovi atributi ili bar oni koji bi se na osnovu njegovih putopisa dali izvesti. A oni se pokazuju kao istiniti jer ih potvrđuje stvarnost:

Nisam mogao da se otmem tome jednakom utisku ampira, koji mi se svuda ukaza u Toskani, kao nešto što umire, na onom što je davno umrlo. Jedino taj ampir još, sa nečim bolesnim u sebi, živi na dnu vrtova, i pod fontanama. 
[...] Oseća se još samo romantično, putem. Ampir Stendala i jedino doba koje se, usput, još može dodirnuti rukom, vreme je parmsko. (Isto: 88)

„Glas“ koji Stendala proglašava za najboljeg poznavaoca italijanskog društva je lično Stendalov, kao i kriterijumi za taj izbor.

Potrebne su godine da bi čovek prodro u intimnost italijanskog društva. Možda sam ja bio poslednji putnik u toj zemlji. Posle karbonara i austrijske najezde, nikad više stranac neće biti primljen kao prijatelj u salonima u kojima je vladala luda veselost. Stranac će u jednom gradu videti spomenike, ulice javne trgove, ali nikad i društvo; ..." (Stendal 1981: 6-7)

\section{Via Casanova i via Sclavi}

Crnjanski, u skladu sa svojom avangardnom poetikom, u Ljubavi u Toskani ogoljava principe građenja putopisa. Postoji svest o tekstualnostil posredovanosti putopisa, ali i samog doživljaja jedne zemlje. Tako se pojavljuje udvostručena slika Italije koja nastaje uzajamnom dekonstrukcijom između Italije u putopisu i boravka u Italiji kao biografske činjenice. Na najvišem nivou ovo znači: od Italije u literaturi, toposa umetnosti, kulture, lepote prirode do fikcionalne Italije na dokumentarnoj podlozi, utopističkog hronotopa i simbola rasta i rađanja.

Najindikativniji primer „ogoljavanja postupka“ je „ulazak u Italiju“. Alpi su važna demarkaciona linija između severa i juga i, naročito, između Italije i ostatka sveta. Shodno tome, ova granica za naš putopis i nije mnogo važna; ona je markirana jedino ako se u Italiju išlo iz drugih krajeva Evrope. U zavisnosti od vrste putopisa i teorije koju autor zastupa, ulazak u Italiju biće različito interpretiran, ali će njegovo spominjanje biti manje-više obavezno i „nabijeno“ emocijama, smislom. Predstava o Italiji, sa kojom putnici kreću od kuće, narasla do mita, a stvorena posredstvom literature, uslovila je sakralizaciju „ulaska" u smislu ostvarenja arhetipskih „želja“: „povratka majci“, „ponovnog rođenja“, „ulaska u raj“, „u večnost“, „u Istoriju“ ili, kao u Geteovom slučaju, u Arkadiju. Uzroci uzbuđenosti i ekstatičnosti se uglavnom racionalizuju, te se otuda u književnosti Italija predstavlja već spomenutim toposima.

Skriveni smisao toposa Crnjanskom je poznat.

Prelaz preko Alpa, iako malo usiljeno, opisuje se još uvek kao dubok doživljaj celog bića i kao vanredan čas duševnih divljenja. Odlazak u Italiju još uvek znači čekanje čuda i put hodočašća, a značaj koji se samome sebi pri tom pridaje, izgleda, u maglovitim planinskim vencima, nad ogromnim svetlim ravnicama, kao sen Hanibalova, čudna, tajanstvena, afrička i veličanstvena, sa svojim mračnim slonovima, na snegu u visinama. (Crnjanski 1995: 160-161)

Ali ovo Crnjanski izgovara na kraju svog putopisa i na kraju svog puta, kad je već „raščaran“. Sasvim drugačije se opisuje „ulazak“ u Italiju, pri čemu on ne spominje ni Alpe, ni to da mu je poznat putopisni topos. 
Jedina eksplicitna veza sa citiranim opisom prelaska je u spominjanju varvara i Hanibala. „Prošli smo bili kroz planine i stene i milovali smo se sa brdima i vidicima, jureći i obilazeći ih. Sišao sam u Italiju lak i providan, sa jednim šljunkom u ruci što je, kotrljajući se s brda, pao u kola, pred jednim tunelom" (Isto: 54 ).

Doživljaj i opis prirode takođe su posredovani različitim ideologijama, uslovljeni književnim obrascima. Jedan od načina za „,razbijanje“ kanonizovanih „opisa-slika“ pejzaža je promena perspektive. Crnjanski do Italije, i kroz Italiju putuje vozom; umesto statične, uvodi se dinamična tačka gledišta. Skoro sve „neobičnosti“ opisa su motivisane što udaljenošću od predmeta opisa, što osvetljenjem. Retko kad da Crnjanski ne spomene odakle šta gleda, a to su najčešće uzvišenja (visoke građevine ili brda). Drugi slučajevi su ređi, ali neobičniji: delovi pejzaža se posmatraju iz neposredne blizine koja ih deformiše jer nije u skladu sa njihovim dimenzijama. Takođe, obično ne propušta da kaže koje je doba dana, pa su neočekivane boje pejzaža samo posledica naročitog osvetljenja (obično suton ili zora). Prilično su česti, i ne slučajno, opisi neba. Nebo je jedini „nestrukturirani“ prostor u putopisu iako se može naći znatan broj putopisaca koji spominju i „,italijansko nebo“.

„Rastakanje“ linearne perspektive, do krajnjih granica, fikcionalizovalo je putopis; ulazak u Italiju je ulazak u fikciju, „ulazak“ u putopis o Italiji, s tim što je odnos realno-fikcionalno udvostručen. „Priviđenja“ su jedan od oblika realizacije tuđih „poetičkih biografema“ i uslovljeni su prethodnom identifikacijom sa drugima, što će naročito biti očigledno u transformaciji motiva „prelaska preko Alpa“. „Gorko želim da izgubim čulnost mladosti i šapućem imena dragana onih koji su prešli Alpe sa jaukom. Dragana koje možda i nisu od krvi i mesa: Vana, Lađa, Mandeta, Selvađa” (Isto: 58). Već prema „imenima dragana“ lako je zaključiti sa kim se on to identifikuje; teže je otkriti šta mu to sve znači. U drugom spominjanju „prelaska sa jaukom“ kaže se odakle motiv potiče; iz jedne pesme Ćina da Pistoje (Isto: 118). I ovde "prelazak preko Alpa” ima veze sa prelaskom granice. Svi ili skoro svi stilnovisti su politički prognanici, pa je onda naravno „prelazak“ „semantizovaniji“. Crnjanski kasnije piše i o raskoraku između njihove poetike i biografije, ali ovde su "činjenice“ i jedne i druge ili željena stanja (,izgubiti čulnost mladosti“) ili „Zajednička osećanja“. Svi ili skoro svi stilnovisti su politički prognanici, pa „prelazak preko Alpa“ ima konotaciju večnog traženja i večnog (ne)nalaženja „majke zemlje“. Citiraćemo nekoliko stihova iz najpoznatije pesme na tu temu:

Jer ne nadam se vratiti u Toskanu, Balado, nikad više,

Ti pođi, lakše, tiše,

Ravno do gospoje moje... 
Balado, ti mi ćutiš da se gasi

Moj život dok me steže smrt ovako...

Tijelo je moje skršeno već tako

Pa trpjeti ne mogu. (Cavalcanti 1986: 65-66)

Međutim, sam „prelazak preko Alpa“ opisan je u jednoj drugoj knjizi, Kazanovinim Memoarima. Posle bolnog rastanka sa Anrijetom u Ženevi Kazanova „prelazi Alpe sa jaukom“. „Izabrao sam put preko San Bernara, mada godišnje doba ne beše za to nimalo podesno ... Kad čoveka satire velik bol, on ima bar tu prednost da mu se ništa ne čini teško. To je kao crno očajanje u kojem ima neke naslade (Casanova 1970II, 140). ${ }^{18}$

Ono što Crnjanskog izdvaja je i njegova misionarska uloga, putuje kao predvodnik „bednih Slovena“. „Propast Zapada“ i „renesansa Slovena" je ideja tog vremena i toliko je raširena da je postala skoro banalna. Crnjanski je donekle podržava, ali u jednom izvornijem obliku, u kakvom je nalazimo kod Dostojevskog, ali i ne samo kod njega. Ima veze sa našom i ruskom putopisnom tradicijom. Ruski pisci su manje zadivljeni Zapadom, odnos prema „evropskom“ je ambivalentan. Zimske beleške o letnjim utiscima su razmišljanje na temu „odlaska u inostranstvo“ i, u stvari, parodična karakterizacija Francuza (Dostojevski 1988). Naši putnici ne samo da strane zemlje gledaju najčešće očima poznatih stranaca, nego počinju i nas da gledaju njihovim očima. "Zadivljenost stranim“ imaće za posledicu preuzimanje poznatih, stranih literarnih konstrukcija koje su u vezi s evrocentričnim određenjem putopisa ${ }^{19}$. Upravo odatle (nesvesni) didaktizam našeg putopisa. Slika Slovena je i ovde posredovana literaturom, ali uglavnom ruskom, po kojoj su Sloveni patnici, a pošto je takva slika za Crnjanskog ipak odviše „hrišćanska“, „mazohistička“, on će nastojati da je neutralizuje. Kao otelotvorenje slovenske duše i slovenske patnje pojavljuje se Gogolj. Da bi sproveo svoju zamisao u Mrtvim dušama (što ipak nije uspeo da uradi) odlazi iz Rusije. „Znao sam da ne putujem da bih uživao u tuđim krajevima, već prvenstveno zato da bih patio - baš kao da sam predosećao da ću vrednost Rusije i ljubav prema njoj spoznati daleko od nje“ (Gogolj 1991, 133). I najveći deo vremena provodi u Italiji ${ }^{20}$ baveći se pitanjem duše. Gogoljeva filozofska /ideološka, ali i poetička pozicija: patnja kao preduslov za pravu umetnost (Isto: 322) dijametralno su suprotne pozicijama koje zauzima Crnjanski, koji i pored toga ne uspeva da se do kraja oslobodi tragičnosti „slovenske sudbine“. Sloveni su najčešće, kao i sv. Franja, predstavljeni slikom-vizijom „igranja

18 Mogu se pratiti različite modifikacije ovog motiva kod različitih pisaca, pre svega Stendala i Bajrona, „spiskovi dragana“, „ljubavne patnje“, opisi švajcarske prirode, odlasci iz domovine (Bajron je bio primoran da to uradi), ali je podelom na "podmotive“ sam motiv desemantizovan i najčešće marginalizovan.

19 Vrlo je zanimljiv Dučićev slučaj o kojem je nešto više pisao V. Gvozden. Reč je o njegovoj identifikaciji sa Francuzima i njegovom udvojenom opisu Balkana (2003).

20 Znamo da je čitao Stendalove Šetnje po Rimu i da im se divio (Erenburg 1965, 138). 
u pejzažu“21 . „Rogati bog 22 igra pred nama, a mi seljaci, napojeni biljem i krvlju životinjskom, igramo, skačemo, urlamo imena reka" (Crnjanski 1995: 62). A u ovom slučaju čak i kao učesnici u Dionizijskim misterijama, misti. Prisustvo Slovena u Toskani oseća se čak i kad nije spomenuto, a njihova uklopljenost u toskanski pejzaž, a posredno i u kulturu, mnogo je veća od uklopljenosti „svetskih putnika“, Crnjanskovih Engleskinja i Amerikanki.

\section{„Hanibalov kompleks": „Da vidim, pa da umrem" i/ili "Bocca della Verita"}

Ovaj odeljak je naslovljen sa tri stereotipa o Italiji, koji, nadamo se, sažimaju sva pisanja o Italiji. Prvi se odnosi na „strah od Rima“ ili na „strah od uspeha“, drugi na ostvarenje „arhetipske“ ili možda pre „zabranjene želje“ ili frojdovski shvaćenog tabua, i treći, koji na izvestan način sadrži i prva dva, zastrašujuće i istovremeno oslobađajuće suočavanje s istinom o sebi i svetu.

Sva tri „straha“, pa i njihova imenovanja, ni manje, ni više, nalazimo u Frojdovoj biografiji. Posle pobede, u Drugom punskom ratu, 217, Hanibal propušta priliku da osvoji Rim; vođen drugačijim mišljenjem kreće na jug, u Apuliju. Frojd će kasnije ovo psihološki tumačiti kao „strah od Rima“ zbog prevelike zadivljenosti i nazvati „Hanibalovim kompleksom“ (Džons 1985II, 16; Klajn 1976, 21-22).

U pozno leto 1901. zbio se događaj koji je imao izuzetan emocionalni značaj za Frojda, događaj koji je on nazvao 'visokom tačkom mog života'. Bila je to poseta Rimu za kojom je toliko čeznuo. ... O postojanoj snazi te čežnje nema ni najmanje sumnje... Ona se očigledno začela još u njegovom dečaštvu, i, kao što je sam rekao, 'ona je postala simbol za izvestan broj žarko negovanih želja'. Mera snage te čežnje je velika sreća, pa čak i zanos koji bi ga obuzeli svaki put kad bi posetio Rim. Opčinjenost njome nije ni na trenutak popuštala, i iz pisma u pismo govori se o toj čežnji jezikom punim oduševljenja“" (Džons 1985II: 15). ... „Za godina svojih dugih putovanja po severnoj i srednjoj Italiji, najvećma se približio Rimu kad je (1897) stigao do Trazimena”. (Isto: 16) „U obzir moramo uzeti dve druge neosporne činjenice. Jedna je da je on citirao Rankovu studiju o simbolici gradova i Majke Zemlje... ovo mesto, koje Frojd navodi kao jednu o varijanti legenda o Edipu, očigledno preokreće ishodišnu ideju da će čovek moći da spava sa svojom majkom tek pošto pobedi neprijatelja. Druga činjenica je Frojdovo davnašnje i strastveno poistovećivanje sa semitskim Hanibalom... Tek posle četiri godine autoanalize Frojd je konačno savladao te otpore, i likujući ušao u Rim. (Isto: 17).... „U ponedeljak, 2.

21 Dionizijko-hrišćanska karakterizacija Slovena prisutna je i u delima A. Belog i Vjačeslava Ivanova. Međutim, u njihovom slučaju bio je preovlađujući hrišćanski momenat, pri čemu je i sam Niče hristijanizovan.

22 Pan. 
septembra 1901, Frojd je u pratnji brata Aleksandra stigao u Rim. Bila je to prva od sedam poseta koje će učiniti Svetom gradu... Bacio je novčić u fontanu $\operatorname{Trevi}^{23}$, zavetujući se da će ubrzo ponovo doći u Rim, što je doista i učinio već sledeće godine. Takođe je gurnuo ruku u 'otvor istine' (Bocca della Verita) u crkvi Sveta Marija in Kosmedin... A sutradan je prvi put (u prvoj od koliko potonjih prilika) osmotrio Mikelanđelov kip Mojsija (Isto: 18).... „Krajem avgusta 1902. smislio je da poseti Napulj i njegovu okolinu. On priča kako je na putu donde naišao na svog dvojnika ${ }^{24}$, i kako je, u jednom od svojih praznovernih raspoloženja, zapitao: 'Znači li to Vedere Napoli e poi morire" (Isto: 19)

Kao što smo videli ovde, Frojd je ne samo dobar poznavalac duše, nego i književnosti. Drugom prilikom smo pokazali da je on odlično poznavao i razumeo memoarsku književnost (Babić 2008), a sada ćemo samo još skrenuti pažnju na njegovo tumačenje Jensenove Gradive, čija radnja je smeštena u Pompeju, a to je mesto i gde je on tumači. Bilo bi zanimljivo, za neko drugo istraživanje, iščitati i Frojdova pisma. I za kraj, jedna „poslastica“ i za teoretičare književnosti, i za psihoanalitičare: Jung nikad nije stigao do Rima: prilikom prve posete Italiji stiže do Ravene i tamo doživljava halucinacije:

Nakon mog iskustva iz Krstionice u Raveni, sa sigurnošću mogu da tvrdim da nešto unutrašnje može delovati kao spoljašnje, i obratno. Stvarne zidove Krstionice, kako sam ih morao videti svojim fizičkim očima, prekrivala je sasvim drugačija vizija, koja je u jednakoj meri delovala realno kao i nepromenljiv sud za svetu vodicu... U toku svog života putovao sam mnogo i veoma sam želeo da idem u Rim, ali sam osećao da nisam dorastao utiscima koje bi taj grad ostavio na mene. Sama Pompeja bila mi je više nego dovoljna: utisci koje je ostavila na mene uskoro su prevazišli moje receptivne moći. Bio sam u stanju da obiđem Pompeju tek pošto sam, kroz proučavanja od 1910. do 1912. godine, stekao izvestan uvid u psihologiju klasične antike. Godine 1912. nalazio sam se na brodu koji je plovio od Đenove do Napulja. Dok se lađa približavala obrisima Rima, stajao sam pored ograde... Uvek sam se čudio ljudima koji odlaze u Rim, kao što bi, recimo, išli u Pariz ili London. ... U mojim poznim godinama, 1949, poželeo sam da ispravim taj propust ali, dok sam kupovao karte, uhvatila me je nesvestica. Nakon toga, planovi za putovanje u Rim otpali su jednom zauvek. (Jung 2005: 285-286)

Moglo bi se reći da je Italija mesto ukrštanja ličnih sa kolektivnim mitovima, mesto iskušenja, ali i iskušavanja, pre svega, sopstvenih kreativnih potencijala i dometa, „suočavanje s istorijom“, možda ne univerzalnom kako neki misle, ali svakako evropskom (zapadnom).

23 Još jedan stereotip, možda sujeverje.

24 Ovo bi bilo zanimljivo čitati uz Crnjanskovu knjigu Kod Hiperborejaca, što ćemo sledećom prilikom i uraditi. 


\section{IZVORI}

Бајрон, Џ. Г. Изабрана ӥисма. Београд: СКЗ, 1985.

Бајрон, Џ. Г. Чајлg Харолg. Београд: Завод за уџбенике и наставна средства, 2005.

Gete, J. H. Putovanje po Italiji. Beograd: Prosveta, 1962.

Stendhal. O umetnosti i umetnicima. Beograd: Kultura, 1957b.

Црњански, Милош. „Љубав у Тоскани“. Пуйойиси I. Београд: Задужбина Милоша Црњанског, 1995.

\section{LITERATURA}

Amon, Filip. „Diskurs podređen pravilima”. Treći program 85. (1990), 202225.

Бабић, Зорица. „Мемоарско читање/писање: о неким особинама суматраистичке поетике”. Свеске 89 (2008), 101-109.

Bohls, E. and Duncan, I. (eds.). Travel writing 1700-1830. Oxford: Oxford UP, 2005.

Bourget, Paul. Utisci s puta Italijom. Zagreb: Tipografija, 1923.

Burkhart, Jakob. Čičerone uvod u uživanje u umetničkim delima Italije. Novi Sad: Izdavačka knjižarnica Zorana Stojanovića, 2006.

Churchill, Kenneth. Italy and English Literature 1764-1930. London: Macmillan, 1993.

Dostojevski, F. M. Zimske beleške. Zapisi iz podzemlja. Kockar. Beograd: Rad, 1988.

Džons, Ernest. Život i delo Sigmunda Frojda I i II. Novi Sad: Matica srpska, 1985.

Erenburg, Ilja. Francuske sveske. Novi Sad: Matica srpska, 1965.

Flober, Gistav. Buvar i Pekiše. Rečnik otrcanih misli. Beograd: Nolit, 1964.

Gete, J. V. Spisi o književnosti i umetnosti. Maksime i refleksije. Beograd: Rad, 1982.

Gogolj, Nikolaj V. Članci i pisma. Beograd: Jugoslavijapublik, 1991.

Gvozden, Vladimir. Jovan Dučić putopisac: Ogledi iz imagologije. Novi Sad: Svetovi, 2003.

Gurevič, Aron. Problemi narodne kulture u srednjem veku. Beograd: Grafos, 1985.

Jung, K. G. Sećanja, snovi i razmišljanja. Beograd: Atos, 1995.

Casanova, G. Memoari, II, Zagreb: Prosvijeta, 1970.

Cavalcanti, Guido. Rime. Banja Luka: Glas, 1986.

Cuddon, J. A. The Penguin Dictionary of Literary Terms and Literary Theory. London: Penguin Books, 1999. 
Casillo, Robert. The Empire of Streotypes: Germaine de Staël and Idea of Italy, New York: Palgrave Macmillan, 2006.

Klaić, Bratoljub. Veliki rječnik stranih riječi. Zagreb: Zora, 1966.

Klajn, Hugo. Predgovor. Psihopatologija svakodnevnog života. Sigmund Frojd. Novi Sad: Matica srpska, 1976. 7-56.

Курцијус, Ернст Роберт. Евройска књижевносӣ и лайински среgюи век. Београд: СКЗ, 1996.

Lafargue, Paul. Počeci romantizma. Zagreb: Zora, 1950.

McCallam, David. "Pique-niquer sur le volcan: une pratique culturelle de Winckelmann a Sade“. French Studies LXIII, 3 (2009), 259-270.

Moe, Nelson. The View from Vesuvius: Italian Culture and the Southern Question. Los Angeles: California UP, 2002.

Morus. Historija seksualnosti. Zagreb: Naprijed, 1967.

Rečnik književnih termina. Beograd: Institut za književnost i umetnost, 1985.

Старобински, Жан. „Псеудоним Стендал“. Неgремано око. Нови Сад: Издавачка књижарница Зорана Стојановића, 2004. 255-314.

Stendhal. Život Henrija Brularda. Zagreb: Zora, 1957a.

Stendal. O ljubavi. Subotica: Minerva, 1979.

Stern, Lorens. Sentimentalno putovanje po Francuskoj i Italiji. Beograd: Rad, 1963.

Stuparević, Olga. „Srpski putopis o Italiji“. Uporedna istraživanja I. Beograd: Institut za književnost i umetnost, 1976, 103-181.

Shackelton, Robert. "Evolution of Montesquieu's Theory of Climate". Revue Internationale de Philosophie, v. 9, 33/34, (1955), 317-329.

Винкелман, J. Ј. Истиорија gревне уметиностии. Сремски Карловци: Издавачка књижарница Зорана Стојановића, 1996.

Zorica Babić

The Picture of Italy in a Travelogue: Goethe, Byron, Stendhal, and Crnjanski

Summary

By opting for the travel literature on Italy, which was the dominant narrative in the $18^{\text {th }}$ and $19^{\text {th }}$ centuries, and partly the $20^{\text {th }}$ century, as well, the author of the paper wanted to demonstrate how it was constructed, and how important it was, not only for the genre, but for literature and culture in general. For at least five centuries, Italy was the exporter of ideas from very banal ones, related to fashion and cuisine, to artistic, scientific, theological and philosophical. More specifically, the travelogue influenced other genres, even non-literary ones. We have also explored different travel-related traditions: it turns out that the English are not only 
the greatest traditionalists, but also anti-traditionalists. And the French do not recognize, in many ways, the Italian primacy. Furthermore, the author has dealt with the relationship between various travel books, i.e. their authors. And in the end, we could see how important traveling was to them as a biographical fact. Even though it is clear that the experience of a country has always been mediated by literature and deeply "enrolled» in a biographical code. And finally, implicitly and on the basis of the given examples, we make a different, broader and new understanding of the travelogue, or the "travel-related". This was also caused by the previous approaches that have not exhausted all the possibilities in studying the travel books, such as narratology, iterology, or travel culture. And closer to him the travel discourse. The author thinks that it is necessary to talk about the "travel-related", as it is about a novelistic, poetic, or fictional one. Therefore, it is necessary to start from the attribute, i.e. quality. It turns out that the travelogue is an emphasis, essentially an intertextual genre. The travel-related is also found in other genres: novels, memoirs, essays, scientific studies, but also in the works of those who are not even writers, psychoanalysts Freud and Jung. It turns out that Jung never arrived in Rome, which has far-reaching consequences for us: the supremacy of Freud over Jung is noted, and his excellent knowledge of travel literature. Here are further individually analyzed travel canons, Goethe and Stendhal, then Byron and Crnjanski, as well as the relationship between them. We consider the influence of Goethe on Stendhal, Winckelmann on Goethe, and De Sade, then de Staël's on Byron and Stendhal. And finally, the influence of Dostoyevsky, Stendhal and Casanova on Crnjanski. The conclusion is that experience is always mediated by literature.

Keywords: travel-related, Italy, textuality, mediation, picture 